Available online at GSC Online Press Directory

GSC Biological and Pharmaceutical Sciences

e-ISSN: 2581-3250, CODEN (USA): GBPSC2

Journal homepage: https://www.gsconlinepress.com/journals/gscbps

(RESEARCH ARTICLE)

\title{
A study on microbial flora and quality of raw and pasteurized milk from Hyderabad Telangana state, India
}

\author{
PM Sameera ${ }^{1}$, P Raja Rao ${ }^{2}$, Suresh A ${ }^{2, *}$ and J Chapla ${ }^{3}$ \\ ${ }^{1}$ SNV Pharmacy Maha Vidyalya, Tarnaka, Hyderabad, India. \\ ${ }^{2}$ College of Technology, OU, Hyderabad, Telangana, India. \\ ${ }^{3}$ Department of Botany, OU, Hyderabad, India.
}

Publication history: Received on 30 March 2020; revised on 08 April 2020; accepted on 11 April 2020

Article DOI: https://doi.org/10.30574/gscbps.2020.11.1.0080

\begin{abstract}
The present study is to investigate the presence of microbial flora and its quality in raw and pasteurized milk. The milk samples were collected from two different locations in Hyderabad region. A total number of twenty samples were studied including two popular brands of pasteurized milk from dairy out lets. The samples were examined for enumeration of microbial flora on TPC (Total Plate Count) and TCC (Total Coliform Count). The range of TPC and TCC are $1.5 \times 10^{8}$ to $1.25 \times 10^{7} \mathrm{CFU} / \mathrm{ml}$ respectively. Purity of pasteurized milk is good in nature. In the present work, preliminary investigations were carried out to ascertain the physicochemical characteristics and nutritional values of various milk samples. Ten raw milk samples and ten pasteurized milk samples from different places of Hyderabad were examined, for a period of six months and analyzed for microbial quality and microbial flora. Pasteurization ensures the quality of milk is up to their required standards.
\end{abstract}

Keywords: Milk, Quality, CFU, TPC, Microbial Flora

\section{Introduction}

Milk is a substitute of meal and it can be consumed by any one and there is no age limit, the milk is consumed purely or by adding with some nutritional substitutes. Milk and milk products are very popular throughout the world. Now a days the people of high body mass are preferring consumption of pasteurized milk and feeling that they may reduce the body weight. Milk acts as a perfect medium for the growth of many microorganisms. Milk contains proteins, carbohydrates, minerals, vitamins and also unsaturated fatty acids. The presence of any type of microorganisms will cause spoilage of milk. The quality of milk depends on the bacterial contamination (Ahamed and Abdellatif, 2013). Two or three decades back the milk was drawn directly from buffalo or cow which was a base for the growth of microorganisms and the cow is a carrier of microbial disease from mother cow to human beings. Due to such apprehension the milk was to be scientifically pasteurized. Further more, microbial tendencies of milk have an effect on the flavor and physicochemical properties of dairy merchandise. Numerous outbreaks of food borne ailments associated with the consumption of pasteurized milk or pasteurized dairy products have been reported (Schmid et al. 2009; Jackson et al. 2011; Sourav et al. 2014).

Raw or processed milk is a good growth medium for the various microorganisms. Raw milk cannot be used as it is highly concentrated and with high viscosity, density and easily not digestible for the humans. Hence, the raw milk is diluted by adding available raw water. This process paves a way for the contamination and spoilage of milk. The consumption of such spoiled milk or contaminated milk will have an impact on the health of the consumers. Microorganisms may additionally contaminate milk at diverse levels of procurement, processing and distribution.

\footnotetext{
* Corresponding author: Suresh A
} 
The presence of useful bacteria and harmful bacteria quantity determines the quality of milk and milk products (Sourav Kumar Banik et al. 2014). This aspect has a role to play on the health of public. The pasteurized milk is nothing but purified and free from bacteria, the pasteurized milk is free from pathogens and arrests the infecting microorganisms.

\section{Material and methods}

\subsection{Sample collection}

Raw milk samples were purchased from local milk vendors and pasteurized milk collected from different local outlets of Hyderabad dairy. A total number of twenty samples were examined, ten samples of raw milk given the name (OUCTR 1 to OUCTR 10) and similarly ten pasteurized milk sample named as (OUCTP1 to OUCTP10). All samples were collected using sample collector ice box at $4^{\circ} \mathrm{C}$ and were transported to laboratory without delay. These samples were collected during January to July 2018 and were preserved.

\subsection{Enumeration of microorganisms}

Serial dilutions of samples were made up to $10^{-7}$ with sterile normal saline waters by following Marjan et al. (2014) method.

\subsection{Microbiological analysis}

In a corning $10 \mathrm{ml}$ test tube, $10 \mathrm{ml}$ of sample raw milk is taken, $1 \mathrm{ml}$ methylene blue is added, and test tube is closed with a cork and mixed thoroughly and kept on water bath for $6 \mathrm{~h}$ at $35^{\circ} \mathrm{C}$. After $6 \mathrm{~h}$ the content in the test tube become colorless showing the methylene blue became colorless. The time taken for the conversion of methylene blue to colorless depends on bacterial contamination. Here the methylene blue oxidizes the microorganisms present in the milk if the microorganisms quantity is high in the milk the time taken to oxidize microorganisms increases. The methylene blue test depends on the ability of bacteria in milk to grow and consume the dissolved oxygen which reduces the oxidation reduction potentials of medium.

\subsection{Total viable bacterial count}

Total viable bacterial count method was done by the following Buchanan et al. (1984).

\subsection{Total Coliform method}

Total coliform determination was done by following Woldermariam and Asres (2017) method.

\subsection{Physico- Chemical Analysis}

\subsubsection{Milkfat}

Milk fat was determine following the technique of Richardson (1985).

\subsubsection{Total Protein}

Total protein was estimated by the following the method suggested by Foley et al. (1974).

\subsubsection{Lactose}

Percent lactose estimated by the method suggested by Mahoney (1988).

\section{Results and discussion}

\subsection{Physicochemical analysis of milk samples}

The results of physicochemical analysis of milk samples were presented in table -1 . The milk procured from different places and dairy shows the $\mathrm{pH}$ values ranging between 6.65 to 7.18. This trends shows the standard of the milk is within the range. The raw milk titratable ability acidity $(0.14 \%)$ is greater than pasteurized milk $(0.12 \%)$. Here the results shows that is no compatibility between $\mathrm{pH}$ and titratable acidity values. Woldemariam and Asres, (2017) worked on the microbial and physicochemical qualities of pasteurized milk from Ethiopia. The reason could be attributed to diluting the raw milk with water and also using the preservatives, this process is aimed at shelf life. The raw milk showed the 
highest specific gravity (1.31), while the specific gravity of milk obtained from other agencies was lower (1.28). These results shows the water adulteration in milk from different outlets. In the present study the presence of total solids from raw milk is $16.3 \%$ where as milk samples collected from different outlets showed $13.45 \%$ which is lower than that of raw milk. The fat content of raw milk is $9.79 \%$, where as pasteurized milk with $8.25 \%$ SNF. This shows the pasteurized milk with less fat content. Fat content of raw milk had a mean value of $6.57 \%$ where as that of pasteurized milk had lesser mean value of $5.20 \%$. The protein content of raw milk is $4.35 \%$ which is more than the pasteurized milk $3.85 \%$. Similarly casein content and lactose content of raw milk shows the values of $3.65 \%$ and pasteurized milk with $4.53 \%$. The results show the raw milk and pasteurized milk values $2.70 \%$ and $3.65 \%$ respectively. Sarkar (2015) worked on the consideration of microorganisms in pasteurized milk from Kolkata.

\subsection{Microbiological analysis}

The total viable bacteria count is the number of bacteria in a sample that can grow and form countable colonies on nutrient agar medium after being held at $37^{\circ} \mathrm{C}$ for $24 \mathrm{~h}$ of incubation period. The results of bacterial distribution of the raw milk samples were presented in Tables $2 \& 3$. All the raw milk samples had high bacterial load which ranged between $1.06 \times 10^{8}$ to $1.62 \times 10^{8} \mathrm{CFU} / \mathrm{ml}$. The most frequent case of high bacterial count is due to unhygienic system of milking, procurement and also preservation system that is storing the milk below 40 $\mathrm{F}$ (Sourav kumar et al.2014). In 2004 Arenas et al., reported that they had found $5.5 \times 10^{6} \mathrm{CFU} / \mathrm{ml}$ and $10^{6}$ to $10^{7} \mathrm{CFU} / \mathrm{ml}$ of the total number of microorganisms in pooled raw milk and pasteurized milk respectively. In 2010 Hossain et al. reported that the CFU was conducted and found the bacterial count ranged between $1.75 \times 10^{6}$ to $1.22 \times 10^{8} \mathrm{CFU} / \mathrm{ml}$ in raw milk.

There are many reasons for the prevalence of microorganism contamination within the milk samples like defect in pasteurization process, handling conditions and/or maintenance of the machinery. Not only this the other factors are the person who is operating the hole pasteurization process should be thoroughly aware of the operational process and he should be good in health conditions and taking care in handling the system. The TVC of the pasteurized milk samples were recorded and they are in the range between $1.28 \times 10^{7}$ to $2.7 \times 10^{7} \mathrm{CFU} / \mathrm{ml}$ Table-3. Hossain et al. (2010) reported that the bacterial colonies in pasteurized milk samples were recorded between $7.5 \times 10^{7}$ to $1.24 \times 10^{8} \mathrm{cfu} / \mathrm{ml}$.

The Total coliform count CFU range in raw milk is $1.06 \times 10^{4}$ to $2.8 \times 10^{4}$ and in procured samples of pasteurized milk the coliform count is nil. Generally the coliform bacteria forms from the dung, bedding materials, usage of polluted water for cleaning purposes and also from polluted soils Woldemariam and Asres, (2017).

Table 1 Physicochemical parameters of raw and pasteurized milk samples

\begin{tabular}{llllllllll}
\hline $\begin{array}{l}\text { Source of } \\
\text { Milk }\end{array}$ & pH & Acidity & $\begin{array}{l}\text { Specific } \\
\text { gravity }\end{array}$ & $\begin{array}{l}\text { Total } \\
\text { Solids\% }\end{array}$ & SNF\% & $\begin{array}{l}\text { Fat } \\
\text { Content\% }\end{array}$ & $\begin{array}{l}\text { Protein } \\
\text { Content\% }\end{array}$ & $\begin{array}{l}\text { Casein } \\
\text { Content\% }\end{array}$ & $\begin{array}{l}\text { Lactose } \\
\text { Content\% }\end{array}$ \\
\hline Raw milk & 6.65 & 0.14 & 1.031 & 16.30 & 9.79 & 6.51 & 4.35 & 3.56 & 4.53 \\
$\begin{array}{l}\text { Pasteurized } \\
\text { milk }\end{array}$ & 7.18 & 0.12 & 1.28 & 13.45 & 8.25 & 5.20 & 3.85 & 2.70 & 3.65 \\
\hline
\end{tabular}

This could possibly expose the milk to high risk of contamination, which in turn promotes the growth of microbes. Coliform count is especially associated with the level of hygiene during production and subsequent handling since they are mainly of fecal origin. Pasteurization controls the growth of coliforms and their presence in the milk. If coliform count exceeds more than ten per ml of pasteurized milk it means milk procured under improper procedures. The existence of coliform bacteria in high proportion is an indication for collecting the milk in poor sanitary conditions. 
Table 2 Microbial flora of raw milk TVC and TCC

\begin{tabular}{llll}
\hline S.NO & RAW MILK SAMPLE & TVC CFU /ml & TCC CFU/ml \\
\hline 1 & OUCTR1 & $1.5 \times 10^{8}$ & $2.8 \times 10^{4}$ \\
2 & OUCTR2 & $1.62 \times 10^{8}$ & $2.7 \times 10^{4}$ \\
3 & OUCTR3 & $1.31 \times 10^{8}$ & $2.8 \times 10^{4}$ \\
4 & OUCTR4 & $1.42 \times 10^{8}$ & $2.5 \times 10^{4}$ \\
5 & OUCTR5 & $1.19 \times 10^{8}$ & $3.7 \times 10^{4}$ \\
6 & OUCTR6 & $1.46 \times 10^{8}$ & $2.1 \times 10^{4}$ \\
7 & OUCTR7 & $1.32 \times 10^{8}$ & $1.7 \times 10^{4}$ \\
8 & OUCTR8 & $1.22 \times 10^{8}$ & $1.37 \times 10^{4}$ \\
9 & OUCTR9 & $1.06 \times 10^{8}$ & $1.95 \times 10^{4}$ \\
10 & OUCTR10 & $1.08 \times 10^{8}$ & $1.06 \times 10^{4}$ \\
\hline
\end{tabular}

Table 3 Microbial flora of pasteurized milk TVC and TCC

\begin{tabular}{llll}
\hline S.NO & RAW MILK SAMPLE & TVC CFU/ml & TCC CFU/ml \\
\hline 1 & OUCTP1 & $1.25 \times 10^{7}$ & Absent \\
2 & OUCTP2 & $2.7 \times 10^{7}$ & Absent \\
3 & OUCTP3 & $1.46 \times 10^{7}$ & Absent \\
4 & OUCTP4 & $1.31 \times 10^{7}$ & Absent \\
5 & OUCTP5 & $1.28 \times 10^{7}$ & Absent \\
6 & OUCTP6 & $1.38 \times 10^{7}$ & Absent \\
7 & OUCTP7 & $1.90 \times 10^{7}$ & Absent \\
8 & OUCTP8 & $1.5 \times 10^{7}$ & Absent \\
9 & OUCTP9 & $1.37 \times 10^{7}$ & Absent \\
10 & OUCTP10 & $1.97 \times 10^{7}$ & Absent \\
\hline
\end{tabular}

The results are presented in Tables $3 \& 4$. A critical perusal of the table 3 reveals that out of 150 raw milk samples tested, $49(33.3 \%)$ samples were found to be good, 59 (39.5\%) samples were fair. The highest numbers of samples were found to be poor $80(53.5 \%)$ and very poor $87(58.5 \%)$. During this study it was found that in the months of May and June 2018 most samples were very poor and this may be due to high temperature prevailing in summer season. Out of 50 pasteurized milk samples, highest number of samples were found to be good 66 (75.5\%) only 5 (10.0\%) samples were found to be very poor, $6(8.3 \%)$ samples were poor and 8 (6.3\%) fair samples were found. In 2006 Chatterjee et al. reported that the raw milk contained higher number of micro flora probably due to contamination from the animal. Bacteria found in manure, soil and water may enter milk due to dairy utensils and milk contact surfaces. Present study showed that $53 \%$ and $49 \%$ of raw milk samples belongs to poor and very poor category, but in case of other milk samples, $86 \%$ of the samples were of good quality due to pasteurization. The study indicated that the dominant microbial flora associated with milk samples are poor in quality in and around Hyderabad. The micro flora identified were in the order of Lactococcus lactis, Escherichia coli, Lactobacillus acidophilus, Bacillus steariothermicus etc. The milk samples which were collected in the months of May and June 2018 through pasteurization, they are poor in quality may be due to high temperatures. 
Table 4 Microbiological quality of raw milk from Hyderabad city

\begin{tabular}{llllll}
\hline Month & Total No & \multicolumn{4}{c}{ Quality of Milk } \\
\cline { 3 - 6 } & of Samples & Very Poor & Poor & Fair & Good \\
\hline January & 25 & $7(17.5 \%)$ & $9(22.5 \%)$ & $15(37.5 \%)$ & $15(37.5 \%)$ \\
February & 25 & $9(22.5 \%)$ & $10(25.0 \%)$ & $14(35.0 \%)$ & $12(22.5 \%)$ \\
March & 25 & $13(32.5 \%)$ & $15(37.5 \%)$ & $10(25.0 \%)$ & $10(25.5 \%)$ \\
April & 25 & $15(37.5 \%)$ & $19(47.5 \%)$ & $7(18.5 \%)$ & $6(16.5 \%)$ \\
May & 25 & $19(47.5 \%)$ & $15(37.5 \%)$ & $5(14.5 \%)$ & $4(12.5 \%)$ \\
June & 25 & $24(52.5 \%)$ & $12(12.5 \%)$ & $8(21.5 \%)$ & $2(6.5 \%)$ \\
Total & 150 & $87(58.0 \%)$ & $80(53.3 \%)$ & $59(39.3 \%)$ & $49(32.3 \%)$ \\
\hline
\end{tabular}

Table 5 Microbial Quality of Pasteurized Milk from Hyderabad City

\begin{tabular}{llllll}
\hline Month & \multirow{2}{*}{$\begin{array}{c}\text { Total No } \\
\text { of Samples }\end{array}$} & Very Poor & Poor & Fair & Good \\
\cline { 2 - 6 } & 10 & $0(0.0 \%)$ & $0(0.0 \%)$ & $1(8.9 \%)$ & $12(100 \%)$ \\
January & 10 & $0(0.0 \%)$ & $0(0.0 \%)$ & $0(0.0)$ & $10(83.5 \%)$ \\
February & 10 & $0(0.0 \%)$ & $0(0.0 \%)$ & $2(17.6 \%)$ & $10(25.5 \%)$ \\
April & 10 & $0(0.0 \%)$ & $0(0.0 \%)$ & $0(0.0 \%)$ & $8(66.5 \%)$ \\
May & 10 & $2(16.8 \%)$ & $2(16.5 \%)$ & $4(14.5 \%)$ & $14(100 \%)$ \\
June & 10 & $3(22.5 \%)$ & $4(34.6 \%)$ & $1(9.6 \%)$ & $12(100 \%)$ \\
Total & 50 & $5(1.0 \%)$ & $6(8.3 \%)$ & $8(6.30 \%)$ & $66(75.5 \%)$ \\
\hline
\end{tabular}

\section{Conclusion}

The current study, conclude that the microbiological quality of most of the milk samples collected from different areas of Hyderabad city were not up to the standards, as indicated by their presence in high quantity of microorganisms and also the presence of coli form bacteria. However with the pasteurization treatment they were found to be safe for the consumption, due to the maintenance of temperature, refrigeration of pasteurized milk samples. If the milk samples were not maintained the standards, the quality of milk will have marked effect on the growth of microorganisms. The presence of microbial population in processed milk indicates defect in processing techniques. Certain microbial counts in the milk samples indicate poor microbial quality of milk, which could flow from poor pasteurization potency or recontamination. If the chemical compositions of the milk analyzed were not in proper proportions there will be an imbalance in the total solids content. 
Consumption of raw milk cause health hazards as milk is extremely at risk because of presence and growth of microorganisms, as it harbors pathogens. Pasteurization is that which is wide adopted and so far a good technique that confirm to some extent destroy active microorganisms and controls the growth of microbes. Scientific pasteurization, storage of processed milk at lower temperatures and dodging of post-pasteurization contamination are the safe methods for storing and supply of milk to the consumer.

\section{References}

[1] Ahmed K and Abdellatif N. (2013). Quality control of milk in the dairy industry. World Journal of Dairy Food Science, 8, 18-26.

[2] Arenas RL et al. (2004). Microbiological and physicochemical changes in genestoso cheese. A Spanish acid curd variety throughout ripening. Food Control, 154, 271-279.

[3] Asres AM and Woldemaria HW. (2017). Microbial and Physicochemical qualities of Pasteurized milk. Journal of Food Processing and Technology, 8(1), 1-5.

[4] Buchanan RE and Gibbon NE. (1984). Bergey`s manual of determinative bacteriology, Baltimore. William and Wilkins Co, New York.

[5] Chatterjee SN, Bhattacharjee I, Chatterjee SK and Chandra G. (2006). Microbiological examination of milk in Tarakeswar, India with special reference to coliforms. African Journal of Biotechnology, 5 (15), 1383-1385.

[6] Foley YJ, Buckley J and Murphy MF. (1974). Commercial testing and product control in the dairy industry. University College Cork.

[7] Fromm HI and Boor KJ. (2004). Characterization of Pasteurized Fluid Milk Shelf-life Attributes. Journal of food science, 69,8 .

[8] Hossain TJ, Mohammad KA and Dwaipayan S. (2010). Chemical and Microbiological Quality Assessment of Raw and Processed Liquid Market Milks of Bangladesh. Research Journal and Diary Sciences, 4(4), 28-34.

[9] Jackson KA, Biggerstaff M, Tobin-D Angelo M, Sweat D, Klos J, Nosari, O, Garrison E, Boothe L, Saathoff-Huber L, Hainstock and Fagan RP. (2011). Multistate outbreak of Listeria monocytogenes associated with Mexican-style cheese made from pasteurized milk among pregnant, Hispanic women. Journal of Food Protection, 74, 949-953.

[10] Mahoney F. (1988). Rural dairy technology-Experiences in Ethiopia. ILCA Manual No. 4.Dairy Technology Unit. ILCA, Addis Ababa, Ethiopia. pp 64.

[11] Marjan A, Kamal KD, Kishore SM and Rashed N. (2014). Drug-resistant bacterial pathogens in milk and some milk products. Nutrition and Food Science, 44(3), 241-248.

[12] Richardson, GH. (1985).Standard methods for the examination of dairy products (15th edn).American Public Health Association, Washington DC, USA.

[13] Ralyea RD, Wiedmann M and Boor KJ. (1998).Bacterial tracking in a dairy production system using phenotypic and ribotyping methods. Journal of Food Protection, 61, 1336-1340.

[14] Sarkar S. (2015).Microbiological considerations; Pasteurized Milk. International Journal of Dairy Science, 10(5), 206-218.

[15] Schmidt VSJ, Kaufmann V, Kulozi U, Scherer S and Wenning M. (2012). Microbial biodiversity, quality and shelf life of microfiltered and pasteurized extended shelf life (ESL) milk from Germany, Austria and Switzerland. International Journal of Food Microbiology, 154, 1-9.

[16] Sourav Kumar B, Kamal Kanta D and Aftab Uddin MD. (2014). Microbiological quality analysis of raw, pasteurized, UHT milk samples collected from different locations in Bangladesh. Stamfors. Journal of Microbiology, 4(1), 5-8.

[17] Woldemariam HW and Asres AM. (2017). Microbial and Physicochemical qualities of Pasteurized milk. Journal of Food Processing and Technology, 8(1), 1-5.

\section{How to cite this article}

PM Sameera, P Raja Rao, Suresh A and J Chapla. (2020). A study on microbial flora and quality of raw and pasteurized milk from Hyderabad Telangana state, India. GSC Biological and Pharmaceutical Sciences, 11(1), 100-105. 